\title{
Investigating the Perception of Public Sector Higher Education Institution Faculty Members about the Influences of Psychological Contract on Organizational Commitment
}

\author{
Kamran Nawaz ${ }^{*}$, Mudassar Usman², Hafiz Ghulam Murtaza Qamar ${ }^{3}$, Muhammad Nadeem³, \\ Umar Usman ${ }^{1}$ \\ ${ }^{1}$ Faculty of Management Sciences, International Islamic University, Islamabad, Pakistan \\ ${ }^{2}$ Faculty of Engineering, Bahria University, Islamabad, Pakistan \\ ${ }^{3}$ Collage of Engineering, University of Sargodha, Sargodha, Pakistan \\ Email: *Kamran.nawaz143@gmail.com, Mudassar.usman114@gmail.com, murtaza.qamar@uos.edu.pk, \\ Nadeem.abdullah@uos.edu.pk, Umarusman4987@gmail.com
}

How to cite this paper: Nawaz, K., Usman, M., Qamar, H.G.M., Nadeem, M. and Usman, U. (2020) Investigating the Perception of Public Sector Higher Education Institution Faculty Members about the Influences of Psychological Contract on Organizational Commitment. American Journal of Industrial and Business Management, 10, 144-159. https://doi.org/10.4236/ajibm.2020.101010

Received: November 25, 2018

Accepted: October 3, 2019

Published: January 14, 2020

Copyright $\odot 2020$ by author(s) and Scientific Research Publishing Inc. This work is licensed under the Creative Commons Attribution International License (CC BY 4.0).

http://creativecommons.org/licenses/by/4.0/

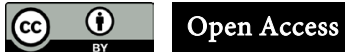

\begin{abstract}
The core aim of this research study is to investigate the consequences of psychological contract on organizational commitment. The context of the study is higher educational Institution International Islamic University Islamabad. Data is collected from 90 faculty members of International Islamic University Islamabad through questionnaire by using the convenience sampling approach. The alpha index is using minimum (0.60) to measure the item reliability. Regression analysis indicates that psychological contract is positively and significantly associated with affective commitment (0.55), continuance commitment (0.74), and the normative commitment (0.69). From the findings, it is concluded that psychological contract is very important for organizational commitment. Higher degree of psychological contract has a result of more organizational commitment. This paper recommended that higher educational institutes should focus on developing a positive and healthy psychological contract with employees. Failure to do so may result in unhealthy psychological contract and can produce negative employee related outcomes.
\end{abstract}

\section{Keywords \\ Psychological Contract, Affective Commitment, \\ Continuance Commitment, Normative Commitment, \\ Regression, IIUI}




\section{Introduction}

Higher educational institutes have high importance for any country because of their role in socio-economic and human resource development of any nation. Pakistan being a developing country also cannot deny the importance of higher educational institutes since if these higher educational institutes play their role properly, then it can increase the process of development. In higher educational context, the human resource play very important role since good staff especially faculty is mainly the source of competitive advantage and if work hard, then can bring high impact on the student life. In this regard, the faculty psychological contract is an important concept. Psychological contract is exchange relationship between employer and employee. Organizational commitment which is another related concept is also important for developing good employee performance and other favorable outcomes. Without having enough organizational commitment among the staff, staff may not be interested in the work and may leave organization as get a new chance.

Generally, private sector institutions experience high staff turnover which seriously reduces their performance and market image. In this regard, psychological contract can provide a useful lens for understanding employee turnover as well as can be used as a useful tool for retaining staff. When employee perceives that their psychological contract is violated by the organization, so they may perceive dissatisfaction and injustice, and may start thinking about leaving the organization. In current research, the focus is on understanding organizational commitment from psychological contract point of view and investigating the relative dependence of organizational commitment of psychological contract. Past studies show the positive aspects of having a strong or positive psychological contract on employees. These favorable outcomes include job satisfaction, work satisfaction, and so on. For example, job stress is also found to be predicted by psychological contract [1] (Bocchino, Hartman, \& Foley, 2003). Further, the relationship between psychological contract and organizational commitment is also found in previous studies [2] (Gumusluoglu, Karakitapoglu-Aygun, \& Hirst, 2013) [3] (Eslami \& Gharakhani, 2012). For example, study conducted by [4] (Lemire \& Rouillard, 2005) investigated the relationship between psychological contract violation and organizational commitment in the context of civil servant employees in a Canadian federal organization. The findings are that psychological contract and commitment is positively associated; while, psychological contract violation is related with contract violation and intention to leave the organization. Another study conducted by [5] (Sturges and Colleagues 2005) investigated the role of psychological contract in career management behavior and help. The findings are that psychological contract fulfillment result in positive job performance and organizational citizenship behavior, while, its violation result in employee intention to quit and other unfavorable workplace behavior. Based on the past studies findings, we are going to investigate the relationship between psychological contract and the organizational commitment in our settings. The hypothetical model is given below which is mainly based on the social 
exchange theory. According to the social exchange theory states that social relationship is based on exchange [6] (Atkinson, 2006). Here it is important to mention that social exchange is not simply a single theory, rather, it is a large set of theories or general framework used in several social and organizational related studies. The social exchange theory supports our model in such a way that it can be successfully used as a lens to understand the psychological contract and employee outcome (commitment) as an exchange relationship. If employers fulfill responsibilities, employees are likely to perceive fulfillment of psychological contract and produce favorable outcomes in return. On the other hand, violation of psychological contract will result in unfavorable outcome.

Finally, this research paper examines the relationship and influence of psychological contract on organizational commitment in term of its three components. Typically, higher education institution faculty members are in consideration for research. The ratio of research on this topic for government institutions is low. It is expecting that this paper fills the gape of research for public sector higher education institutions especially IIUI for this topic. Psychological contract is taking as an independent variable and research is focusing to find its relative influence on Affective Commitment, Continuance Commitment and Normative Commitment.

\subsection{Problem Statement}

This research paper associated with its core aim to investigate the effect of Psychological contract on organizational commitment. It is a research gape to work on "Influences of Psychological contract on organizational commitment" for public sector institutions like IIUI. The employees of government sector institutions are not mainly focused by the researchers. At the end of testing the hypothesis, this research paper providing facts about the association of Psychological contract with organizational commitment of the faculty members of a public sector institution. Furthermore, this research study finds either the Psychological contract has positively influence the organizational commitment or not.

\subsection{Research Question}

- How psychological contract influence on employee affective commitment?

- How psychological contract influence on employee continuance commitment?

- How psychological contract influence on employee normative commitment?

\subsection{Research Objective}

- To investigate the influences of psychological contract on employee affective commitment;

- To investigate the influences of psychological contract on employee continuance commitment;

- To investigate the influences of psychological contract on employee normative commitment. 


\section{Literature Review}

This section provides review of literature on employee psychological contract and employee organizational commitment.

\subsection{Psychological Contract}

Psychological contact is employee understanding and perception of the exchange relationship between what employees gives to the organization and what the organization gives in return [7] (Cassar \& Briner, 2011). Psychological contract also refers to the beliefs an individual held related to the implicit terms of agreements between individual and his/her organization [8] (Rousseau, 1995, 2000). The psychological contract can be classified in to two aspects including transactional and relational [8] (Rousseau, 1995, 2000). The transactional contract is based on the satisfaction from both sides based on the material benefits. The relational contract is based on the satisfaction gained from both sides based on social affection. When employee feels that their agreement (psychological contract) between them and organization is fulfilled, it results in increased job performance and other favorable outcomes [5] (Sturges, Conway, Guest, \& Liefooghe, 2005). On the other hand, if such psychological contract is perceived to be unfulfilled, then it may result in negative outcomes such as turnover, work withdrawal and so on.

Research related to the outcome of psychological contract violation and fulfillment shows that when psychological contract is violated, it results in negative outcomes. For example, a study conducted by [9] (Deery, Iverson, and Walsh 2006) used sample from customer service employees; and find out that when psychological contract is violated, it results in increased absenteeism and decreased trust towards organization. Beside on other factors, Psychological contract has a significant role to keep employee motivated with organizations. The organizations which have more employees' Psychological contract, such organizations have more employees' job commitment \& citizenship behavior [7] (Cassar \& Briner, 2011).

Another study conducted by [10] (Robinson and Rousseau, 1994) examined the relationship between psychological contract violation and different outcomes. Their findings were that when psychological contract is violated, it associates negatively with violations and trust, satisfaction, and intention to remain within organization. Another study conducted by [11] (Chrobot-Mason, 2003) examined the moderating role of trust between the psychological contract violation and organizational cynicism. Research found that when under the situation of high trust by individual, when psychological contract is violated, it is more likely to results in feeling of cynicism compare to the individuals having low level of trust. Research related to the influence of individual and group also shows that perceived psychological contract is also influenced by friends who may hold similar beliefs regarding the fulfillment of the psychological contract [12] (Ho \& Levesque, 2005). 


\subsection{Organizational Commitment}

Organizational commitment is the employee's psychological perception of the relationship between individuals and organizations and it reflects employee psychological status of being loyal to the organization [13] (Meyer and Allen, 1991). Organizational commitment is about psychological status between employees and organization. Organizational commitment is important since it result in employee's intention to stay or leave the organization. The three dimensions of organizational commitment are affective commitment, normative commitment, and continuance commitment [13] (Meyer and Allen, 1991). The three components model of organizational commitment given by [13] (Meyer and Allen, 1991) is an important model since it not only categorizes organizational commitment, but also greatly facilitated commitment related research. Based on the model, affective commitment is about emotional attachment and organizational involvement. Continuance commitment is about perceived cost of leaving the organization. Finally, normative commitment is about sense of obligation to stay within current organization. Past studies show that normative commitment along with the pairing of affective commitment leads to several favorable employee related outcomes and behavior [14] (Gellatly, meyer, \& Luchak, 2006). Relationship between organizational commitment and intention to stay is also established in previous studies [15] (Wasti, 2005; Glazer \& Beehr, 2005). Relationship between organizational commitment and job satisfaction is also established in past studies [16] (Clugston, 2000). Employees are more jobs committed if they have perception that organization is being working also for their interests [17] (Kamran Nawaz, Mudassar Usman, 2018). The employees who are emotionally attached with the organizations have more degree of work commitment. Beside on working hours, such employees work for organization at their highest level [16] (Clugston, 2000). If an organization have less degree of person-organization fit than the employees are not creative and nor performs the tasks in best way. In this situation, workers are not emotionally engaged with their works. Therefore, employees either want to leave the organization or being fired by institutions. This situation negatively affects the continuance commitment of employees [17] (Kamran Nawaz, Mudassar Usman, 2018). The organizations which have high degree of systemic organizational justice, this will affect the employee's affective \& normative commitments both in positive way. In these organizations, the state of mind of employees about organization is positive and they want to stay long term with organization [18] (Sieger, P., Bernhard, F., \& Frey, U. 2011). In any working place, the both side trust $\mathrm{b} / \mathrm{w}$ employee $\&$ employer are very important. High degree of trust shows more affective commitment of employees with organization. In these circumstances, employees do not want to leave the organization and their organizational commitment enhanced [19] (Zeinabadi, H., \& Salehi, K. 2011). Organizational justice affects the organizational commitment of employees. If organization treated the employees equally, providing equal chance for career path and also address the employee's interests than they have more 
organization committed work force. They have also low turnover ratio and workers have proud to be part of such organization [20] (Zubair Aslam, Amir Javed, 2018).

Different theories and researches describe influence of psychological contract on organizational commitment with different fact in their settings.

The proposed hypothesis is for this research work:

\subsection{Proposed Hypothesis for Research}

\section{$H_{1}$ : There is positive influence of psychological contract on affective commitment.}

$H_{2}$ : There is positive influence of psychological contract on continuance commitment.

$H_{3}$ : There is positive influence of psychological contract on normative commitment.

\section{Research Methodology}

This section is providing details on research methodology adapted for conducting the current research study. Details regarding different aspects of research methodology are as under.

\subsection{Population and Sampling}

The study is conducted at International Islamic university Islamabad. The total employees in this organization are about 500. Based on the sample size calculator table provided by [21] (Bartlett, Kotrlik, and Higgins. 2001) the required sample size is 90 . Sample will be drawn across the academic staff Lecturers, assistant professor, associate professor and professors at the university through convenience sampling technique. Structured closed ended questionnaire will be used as main method of data collection.

\subsection{Data Collection and Instrument}

This research is consisting of three parts. First part is about basic demographic questions. Second part is used for measuring psychological contract adapted from [10] (Rousseau, 2000). The measure is based on two dimensions including perceived psychological contract by employer and perceived psychological contract by employees and consists of 4 items. Organizational commitment is measured by measure adapted from [13] (Meyer and Allen, 1991). In this measure, there are 8 items for measuring affective commitment, 8 items for measuring normative commitment, and 8 items for measuring continuance commitment. Reliability test is applied by following the minimum criteria of 0.60 for acceptance. The value of alpha is above than 0.60 so it is reliable for research.

\subsection{Data Analysis Methodology}

The analysis is based on statistical method including Reliability statistics, de- 
scriptive statistic, and regression analysis. SPSS used for data analysis. The value of alpha for Psychological Contract is 0.61 . The values of alpha for the components of dependent variable organizational commitment Affective Commitment, Continuance Commitment and Normative Commitment are 0.76, 0.72, and 0.81 respectively. Values are above than the minimum criteria of alpha reliability 0.60 so acceptable for research.

\subsection{Results \& Discussion}

The following chapter intends to provide results and discussion. Figure 1 shows the model for research with both variables. As Figure 1 is showing the psychological contract and effect on organizational commitment of employees whereas, Figure 2 showed the demographic information of the survey participants as follow:

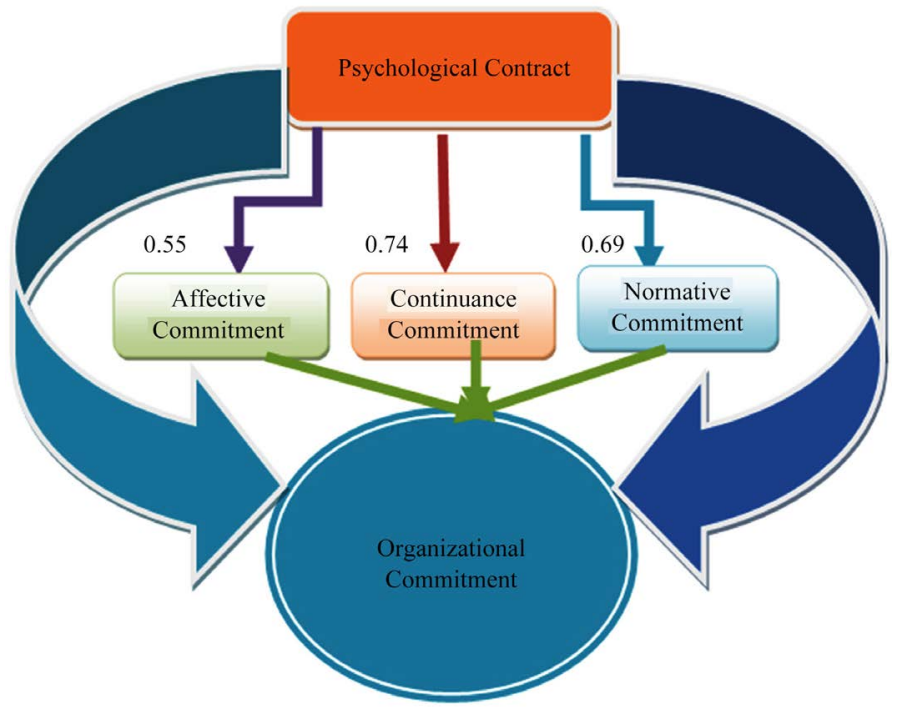

Figure 1. Hypothetical model I for research.

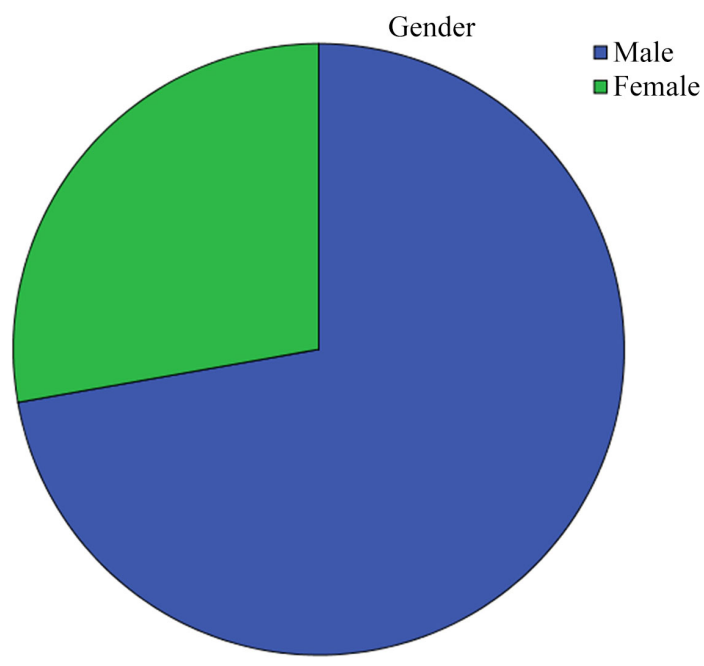

Figure 2. Gender of the participants. 


\section{Demographic Information of the Participants}

Demographic information including gender, age, related to the participants of this research study is as under.

Table 1 showed the participants with respect to gender. There were total of 65 male and 25 female respondents. The higher proportion of male participation in the research is due to the higher number of male workers in the selected organization. Figure 2 also shows the blue as a majority which is for male respondents as well.

Table 2 shows the participants belonged to the age group of 18 to 30 years of age. 48 participants belonged to the 30 to 40 years of age. 15 participants belonged to the age group of 40 to 50 years of age. Finally, 5 participants belonged to the above 60 years of age.

Figure 3 shows also the age groups of participants. Green is $30-40$ years of old which are majority respondent in the research.

Table 3 shows that there are total of 25 lecturer's participants in the research study. 40 assistant professors participated in the survey. 11 associate professors participated in survey. Finally, 14 professors participated in this research work.

Figure 4 is showing the participants designation ratio: Assistant Professor, lecturers, Professor and Associate Professor respectively.

Table 1. Gender ratio.

\begin{tabular}{ccccc}
\hline & Frequency & Percent & Valid Percent & Cumulative Percent \\
\hline Male & 65 & 72.2 & 72.2 & 72.2 \\
Female & 25 & 27.8 & 27.8 & 100.0 \\
Total & 90 & 100.0 & 100.0 & \\
\hline
\end{tabular}

Table 2. Age group.

\begin{tabular}{ccccc}
\hline & Frequency & Percent & Valid Percent & Cumulative Percent \\
\hline 18 to 30 Years & 3 & 3.3 & 3.3 & 3.3 \\
30 to 40 Years & 48 & 53.3 & 53.3 & 56.7 \\
40 to 50 years & 15 & 16.7 & 16.7 & 73.3 \\
50 to 60 Years & 19 & 21.1 & 21.1 & 94.4 \\
Above 60 years & 5 & 5.6 & 5.6 & 100.0 \\
Total & 90 & 100.0 & 100.0 & \\
\hline
\end{tabular}

Table 3. Participants designation.

\begin{tabular}{ccccc}
\hline & Frequency & Percent & Valid Percent & Cumulative Percent \\
\hline Lecturer & 25 & 27.8 & 27.8 & 27.8 \\
Assistant Professor & 40 & 44.4 & 44.4 & 72.2 \\
Associate Professor & 11 & 12.2 & 12.2 & 84.4 \\
Professor & 14 & 15.6 & 15.6 & 100.0 \\
Total & 90 & 100.0 & 100.0 & \\
\hline
\end{tabular}




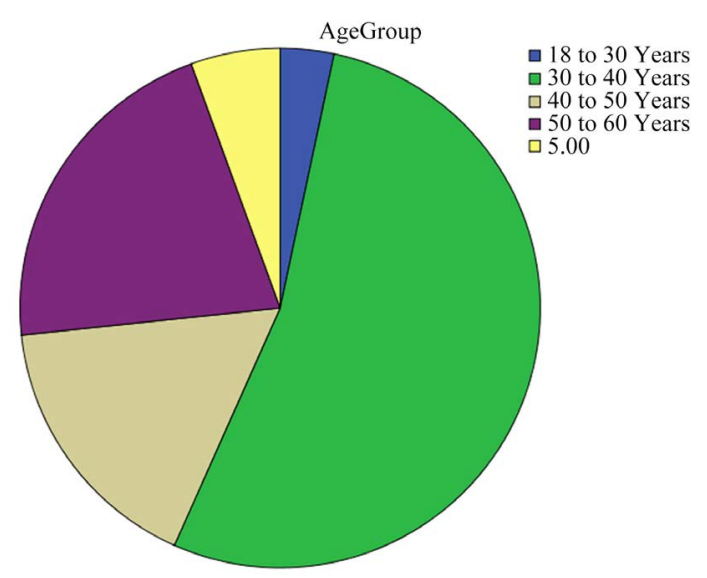

Figure 3. Age group of participants.

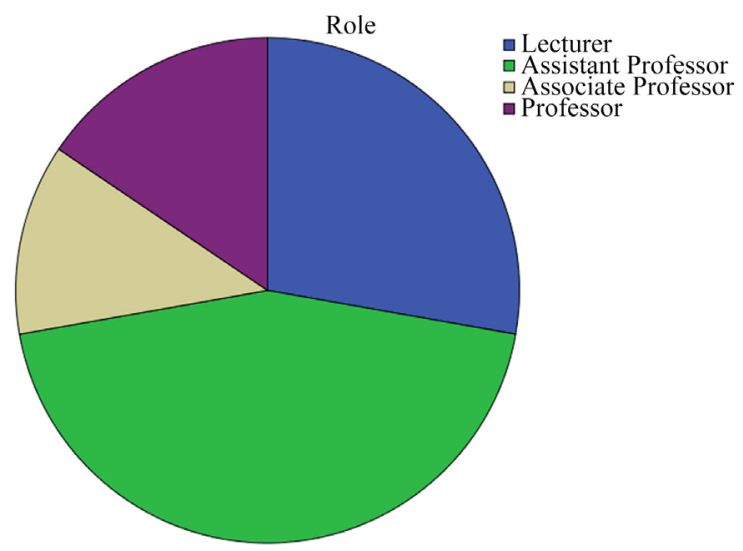

Figure 4. Participants designation.

\subsection{Reliability Statistics}

Table 4 shows the value of reliability alpha for the variables. Psychological Contract is measured by 4 items with value 0.61 . Affective commitment is measured by 8 items with value of 0.762 . Continuance and Normative Commitments also measured by 8 items with alpha values of 0.72 and 0.814 respectively.

\subsection{Descriptive Statistics}

Descriptive statistics for the variables in the study are given below.

Table 5 shows descriptive statistics suggest that participants in the selected organization only moderately satisfied with the psychological contract $(\mathrm{M}=$ $3.10, \mathrm{SD}=0.80)$. Further, the affective commitment $(\mathrm{M}=3.33, \mathrm{SD}=0.67)$; continuance commitment $(\mathrm{M}=3.28, \mathrm{SD}=0.68)$; and normative commitment $(\mathrm{M}=$ $3.37, \mathrm{SD}=0.76)$ are also just around average level in the selected organization. Figure 5 also is also showing findings of Table 5. It is showing the value of mean and standard deviation values.

\subsection{Regression Analysis}

Regression analysis is used for testing the relationship between psychological 
contract and employee commitment. For this purpose, there were three regression models used and in each model, the dependent variables changed based on the three dimensions of organizational commitment. Results are as under.

\subsubsection{Regression Analysis for Affective Commitment}

Table 6 shows the regression results for the effects of psychological contract on affective commitment are given in the table above. $\mathrm{R}$ value indicates that psychological contract and affective commitment are $55.7 \%$ positively associated. Further, the R square value indicates that psychological contact explains 33.3\% change in the dependent variable of affective commitment. The beta value shows that one unit increase in psychological contract will bring 0.482 increase in the affective commitment and the relationship is significant $(t>2)$. The F statistics suggest that model is fit and significant (Fstat $=43.918, \mathrm{P}<0.05)$.

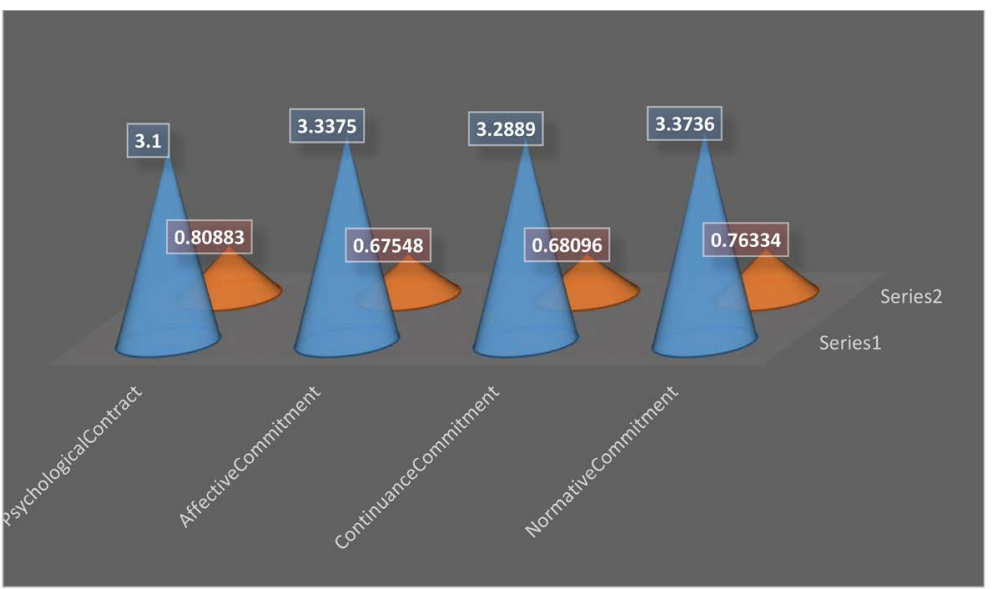

Figure 5. Descriptive statistics-mean and standard deviation.

Table 4. Reliability statistics.

\begin{tabular}{ccc}
\hline Variables & Cronbach Alpha & No. of items \\
\hline Psychological Contract & 0.616 & 04 \\
Affective Commitment & 0.762 & 08 \\
Continuance Commitment & 0.729 & 08 \\
Normative Commitment & 0.814 & 08 \\
\hline
\end{tabular}

Table 5. Descriptive statistics.

\begin{tabular}{ccccccc}
\hline & N & Minimum & Maximum & Mean & $\begin{array}{c}\text { Std. } \\
\text { Deviation }\end{array}$ & $\begin{array}{c}\text { Cronbach } \\
\text { alpha }\end{array}$ \\
\hline Psychological Contract & 90 & 1.25 & 5.00 & 3.1000 & 0.80883 & 0.616 \\
Affective Commitment & 90 & 1.25 & 4.75 & 3.3375 & 0.67548 & 0.762 \\
Continuance Commitment & 90 & 1.38 & 4.63 & 3.2889 & 0.68096 & 0.729 \\
Normative Commitment & 90 & 1.00 & 4.75 & 3.3736 & 0.76334 & 0.814 \\
Valid N (listwise) & 90 & & & & & \\
\hline
\end{tabular}


Table 6. Regression Model 1 for affective commitment.

\begin{tabular}{ccccccc}
\hline & \multicolumn{2}{c}{ Un-standardized Coefficients } & Standardized Coefficients & \multirow{2}{*}{ Sig. } \\
\cline { 2 - 4 } & $\mathrm{B}$ & Std. Error & Beta & & \\
\hline (Constant) & 1.844 & 0.233 & & 7.918 & 0.000 \\
Psychological Contract & 0.482 & 0.073 & 0.577 & 6.627 & 0.000 \\
\hline
\end{tabular}

$\mathrm{R}=0.557$, Rsquare $=0.333$, Fstat $=43.918(0.000)$. a. Dependent Variable: Affective Commitment.

\subsubsection{Regression Analysis for Continuance Commitment}

Table 7 shows the regression results for the effects of psychological contract on continuance commitment are given in the table above. $\mathrm{R}$ value is describing that psychological contract and continuance commitment is $74.7 \%$ positively associated. Further, the R square value represents that psychological contact explains $55.8 \%$ change in the dependent variable of continuance commitment. The beta value shows that one unit increase in psychological contract will bring 0.629 increase in the continuance commitment and the relationship is significant $(t>2)$. The F statistics suggest that model is fit and significant $($ Fstat $=111.111, \mathrm{P}<$ $0.05)$.

\subsubsection{Regression Analysis for Normative Commitment}

Table 8 is showing the regression result for the effects of psychological contract on normative commitment is given in the table above. $\mathrm{R}$ value shows that psychological contract and normative commitment are $69.5 \%$ positively associated. Further, the $\mathrm{R}$ square value is showing that psychological contact explains $48.3 \%$ change in the dependent variable of normative commitment. The beta value shows that one unit increase in psychological contract will bring 0.656 increase in the normative commitment and the relationship is significant $(t>2)$. The $F$ statistics suggest that model is fit and significant (Fstat $=82.302, \mathrm{P}<0.05)$.

\subsection{Discussion on Results}

The objective of the study was to see the effects of psychological contract on employee commitment in the context of higher educational institutes. The hypothetical model showing in Figure 1 explains the aim of study. For this purpose of analysis, a single university is selecting, and data was collected through survey questionnaire. The findings indicate that psychological commitment is having positive and significant effects on employee's affective commitment, continuance commitment, and the normative commitment. The findings are consistent with the findings of previous studies. For example, studies including [4] (Lemire \& Rouillard, 2005) and [5] (Sturges and Colleagues, 2005) founded positive outcomes of psychological commitment including employee's commitment. Further, other studies also found other favorable outcomes of psychological commitment such as job satisfaction, lower job stress, and higher performance [1] (Bocchino, Hartman, \& Foley, 2003); [5] (Sturges, Conway, Guest, \& Liefooghe, 2005); [8] (Rousseau, 2000). Thus, it can be concluded that psychological contract result in favorable outcomes including employee commitment. 
Table 7. Regression Model 2 for continuous commitment.

\begin{tabular}{|c|c|c|c|c|c|}
\hline & \multicolumn{2}{|c|}{ Un-standardized Coefficients } & \multirow{2}{*}{$\begin{array}{c}\text { Standardized Coefficients } \\
\text { Beta }\end{array}$} & \multirow{2}{*}{$\mathrm{t}$} & \multirow{2}{*}{ Sig. } \\
\hline & B & Std. Error & & & \\
\hline (Constant) & 1.339 & 0.191 & & 7.009 & 0.000 \\
\hline Psychological Contract & 0.629 & 0.060 & 0.747 & 10.541 & 0.000 \\
\hline
\end{tabular}

$\mathrm{R}=0.747$, Rsquare $=0.558$, Fstat $=111.111(0.000)$. a. Dependent Variable: Continuance Commitment.

Table 8. Regression Model 3 for normative commitment.

\begin{tabular}{cccccc}
\hline & \multicolumn{2}{c}{ Un-standardized Coefficients } & Standardized Coefficients & & Sig. \\
\cline { 2 - 3 } & $\mathrm{B}$ & Std. Error & Beta & & \\
\hline (Constant) & 1.340 & 0.232 & & & \\
\hline Psychological Contract & 0.656 & 0.072 & 0.695 & 0.000 \\
\hline $\mathrm{R}=0.695$, Rsquare $=0.483$, Fstat $=82.302$ & $(0.000)$. a. Dependent Variable: Normative Commitment.
\end{tabular}

\section{Conclusion}

The core purpose of this research paper is to investigate the influences of psychological contract on organizational commitment of employees. Psychological contract is measured through 4 items developed by [8] (Rousseau 2000). The three dimensions of organizational commitment, affective commitment, normative commitment and continuance commitment is measured through [13] (Meyer and Allen, 1991). This research paper confirms the positive influences of psychological contract on affective commitment, normative commitment and continuance commitment. If employer seems to be fulfilling his/her responsibilities, employee will perceive it favorably and may in return work for positive outcomes such as performance or be more committed. On the other hand, if psychological contract is violated or expectations are not fulfilled, then employee's commitment may be decreased which may lead to unfavorable outcomes. In higher educational context, thus, maintaining a healthy psychological contract is very important as it will help universities and other higher educational setups to retain staff. Having a poor psychological contract with the staff will result in high turnover among faculty which will undermine the performance and goodwill of the universities. Thus, we can conclude that psychological contract is very important and have significant positive influences on employee commitment so this concept especially in higher educational context should not be ignored by the management.

\section{Limitations and Future Research Directions}

The limitations of the study are that it only focused on one aspect which was the psychological contract and employee commitment. Other relevant aspects were excluded. Further, the sample size is small and only drawn from single organization which is also its limitation. This research paper discussed the influence of psychological contract on employee commitment, but many other factors will also important for employee commitment neglected. Psychological contract is 
also important for employee creativity and innovative behaviors. Employees are more innovative work behaviors if they have high degree of psychological contract [19] (Zeinabadi, H., \& Salehi, K. 2011). This is expecting that this will paper help researchers and organizations for understanding of relative impotence of psychological contract. This is also expecting that other factors like organizational justice, person-organization fit which play role for job commitment of employees will research by researchers and scholars.

\section{Conflicts of Interest}

The authors declare no conflicts of interest regarding the publication of this paper.

\section{References}

[1] Bocchino, C.C., Hartman, B.W. and Foley, P.F. (2003) The Relationship between Person-Organization Congruence, Perceived Violations of the Psychological Contract, and Occupational Stress Symptoms. Consulting Psychology Journal: Practice and Research, 55, 203-214. https://doi.org/10.1037/1061-4087.55.4.203

[2] Gumusluoglu, L., Karakitapoglu-Aygun, Z. and Hirst, G. (2013) Transformational Leadership and R \& D Workers' Multiple Commitments: Do Justice and Span of Control Matter? Journal of Business Research, 66, 2269-2278. https://doi.org/10.1016/j.jbusres.2012.02.039

[3] Eslami, J. and Gharakhani, D. (2012) Organizational Commitment and Job Satisfaction. ARPN Journal of Science and Technology, 2, 85-91.

[4] Lemire, L. and Rouillard, C. (2005) An Empirical Exploration of Psychological Contract Violation and Individual Behaviour: The Case of Canadian Federal Civil Servants in Quebec. Journal of Managerial Psychology, 20, 150-163.

https://doi.org/10.1108/02683940510579786

[5] Sturges, J., Conway, N., Guest, D. and Liefooghe, A. (2005) Managing the Career Deal: The Psychological Contract as a Framework for Understanding Career Management, Organizational Commitment and Work Behavior. Journal of Organizational Behavior, 26, 821-838. https://doi.org/10.1002/job.341

[6] Atkinson, C. (2006) Trust and the Psychological Contract. Employee Relations, 29, 227-246. https://doi.org/10.1108/01425450710741720

[7] Cassar, V. and Briner, R. (2011) The Relationship between Psychological Contract Breach and Organizational Commitment: Exchange Imbalance as a Moderator of the Mediating Role of Violation. Journal of Vocational Behavior, 78, 283-289. https://doi.org/10.1016/j.jvb.2010.09.007

[8] Rousseau, D.M. (1994, 2000) Psychological Contract Inventory. Technical Report, Carnegie Mellon University, Pittsburgh, PA.

[9] Deery, S.J., Iverson, R.D. and Walsh, J.T. (2006) Toward a Better Understanding of Psychological Contract Breach: A Study of Customer Service Employees. Journal of Applied Psychology, 91, 166-175. https://doi.org/10.1037/0021-9010.91.1.166

[10] Robinson, S.L., Dirks, K.T. and Ozcelik, H. (2004) Untangling the Knot of Trust and Betrayal. In: Kramer, R.M. and Cook, K.S., Eds., Trust and Distrust in Organizations, Russell Sage Foundation, New York, 327-341.

[11] Chrobot-Mason, D.L. (2003) Keeping the Promise: Psychological Contract Violations for Minority Employees. Journal of Managerial Psychology, 18, 22-45. 


\section{https://doi.org/10.1108/02683940310459574}

[12] Ho, V.T. and Levesque, L.L. (2005) With a little Help from my Friends (and Substitutes): Social Referents and Influence in Psychological Contract Fulfillment. Organization Science, 16, 275-289. https://doi.org/10.1287/orsc.1050.0121

[13] Meyer, J.P. and Allen, N.J. (1997) Commitment in the Workplace: Theory, Research and Application. Sage, Thousand Oaks, CA.

[14] Gellatly, I.R., Meyer, J.P. and Luchak, A.A. (2006) Combined Effects of the Three Commitment Components on Focal and Discretionary Behaviors: A Test of Meyer and Herscovitch's Propositions. Journal of Vocational Behavior, 69, 331-345. https://doi.org/10.1016/j.jvb.2005.12.005

[15] Wasti, S.A. (2005) Commitment Profiles: Combinations of Organizational Commitment Forms and Job Outcomes. Journal of Vocational Behavior, 67, 290-308. https://doi.org/10.1016/j.jvb.2004.07.002

[16] Clugston, M., Howell, J.P. and Dorfman, P.W. (2000) Does Cultural Socialization Predict Kmultiple Bases and Foci of Commitment? Journal of Management, 26, 5-30. https://doi.org/10.1177/014920630002600106

[17] Nawaz, K. and Usman, M. (2018) Impact of Person-Organization Fit on Employee Creativity. Arabian Journal of Business and Management Review, 8, No. 4.

[18] Philipp, S., Fabian, B. and Urs, F. (2011) Affective Commitment and Job Satisfaction among Non-Family Employees: Investigating the Roles of Justice Perceptions and Psychological Ownership. Journal of Family Business Strategy, 2, 78-89. https://doi.org/10.1016/j.jfbs.2011.03.003

[19] Zeinabadi, H. and Salehi, K. (2011) Role of Procedural Justice, Trust, Job Satisfaction, and Organizational Commitment in Organizational Citizenship Behavior (OCB) of Teachers: Proposing a Modified Social Exchange Model. Procedia-Social and Behavioral Sciences, 29, 1472-1481. https://doi.org/10.1016/j.sbspro.2011.11.387

[20] Aslam, Z. and Javed, A. (2018) Effect of Organizational Justice on Job Satisfaction in Universities of Pakistan. Journal of Business \& Financial Affairs, 7, 338.

[21] Bartlett, J.E., Kotrlik, J.W. and Higgins, C.C. (2001) Determining Appropriate Sample Size in Survey Research. Information Technology, Learning, and Performance Journal, 19, 43-50. 


\section{Appendix: Survey Questionnaire}

Gender:

- Male

- Female

Age Group:

- 18 to 30 Years

- 30 to 40 Years

- 40 to 50 Years

- 50 to 60 Years

Role:

- Lecturer

- Assistant Professor

- Associate Professor

- Professor

- Others

Note: $1=$ Not at all, to $5=$ to a great extent

Overall, how well does your employer fulfill its commitments to you?

$\begin{array}{llll}1 & 2 & 3 & 4\end{array}$

4

Psychological

In general, how well does your employer live up to its promises to you?

Contract

Overall, how well have you fulfilled your commitments to organization?

Overall, how well have you fulfilled your promises to organization

I would be very happy to spend the rest of my career with this organization

I enjoy discussing about my organization with people outside it

I really feel as if this organization's problems are my own

Affective

Commitment

I think that I could easily become as attached to another organization

as I am to this one $(\mathrm{R})$

I do not feel like "part of the family" at my organization (R)

I do not feel "emotionally attached" to this organization (R)

This organization has a great deal of personal meaning for me

I do not feel a "strong" sense of belonging to my organization (R)

Note: $1=$ Strongly Disagree, $2=$ Disagree, $3=$ Neutral, $4=$ Agree, $5=$ Strongly Agree

I am not afraid of what might happen if I quit my job without having another one lined up (R)

$\begin{array}{lllll}1 & 2 & 3 & 4 & 5\end{array}$

It would be very hard for me to leave my organization right now, even if I

wanted to

Too much in my life would be disrupted if I decided to leave my

organization now

It wouldn't be too costly for me to leave my organization now (R)

Continuance

Right now, staying with my organization is a matter of necessity as much as desire

I feel that I have very few options to consider leaving this organization

One of the few serious consequences of leaving this organization would be the scarcity of available alternatives

One of the major reasons I continue to work for this organization is that leaving would require considerable personal sacrifice-another organization may not match the overall benefits I have here* 


\title{
Continued
}

I think that people these days move from company to company too often

I do not believe that a person must always be loyal to his or her organization (R)

Jumping from organization to organization does not seem at all unethical to me (R)

One of the major reasons I continue to work in this organization is that I

Normative believe loyalty is important and therefore feel a sense of moral obligation to remain

If I got another offer for a better job elsewhere I would not feel it was right to leave my organization

I was taught to believe in the value of remaining loyal to one organization

Things were better in the days when people stayed in one organization for most of their career

I do not think that to be a "company man" or "company woman" is sensible anymore (R)

\author{
Abbreviations \\ IIUI = International Islamic university Islamabad \\ $\mathrm{OC}=$ Organizational Commitment \\ $\mathrm{VC}=$ Vice Chancellor \\ $\mathrm{PC}=$ Psychological Contract
}

